\title{
橋梁の近接目視点検を支援する 飛行ロボットシステムの開発* \\ Unmanned Aerial Vehicle for Supporting Close Visual Inspection of Bridges
}

\section{大野和則 ${ }^{* *}$ 岡田佳都 ${ }^{* * *}$ 原島正豪 ${ }^{\dagger}$ 横江政和 ${ }^{\dagger \dagger}$ \\ Kazunori OHNO, Yoshito OKADA, Seigo HARASHIMA and Masakazu YOKOE}

Key words ドローン, 橋梁点検, 近接目視, Visual SLAM

\section{1. は じめに}

内閣府総合科学技術・イノベーション会議の「SIP イ ンフラ維持管理・更新・マネジメント技術」(管理法人： NEDO）の支援を受けて, 開発を進めている橋梁点検用の 飛行ロボットシステムについて説明する。本成果は, 東北 大学，株式会社リコー，千代田コンサルタント株式会社， （一財）航空宇宙技術振興財団，東急建設株式会社の共同 研究の産物である.

私たちは，橋梁の近接目視点検を支援・代替する飛行口 ボットシステムを開発している(図 1)。理由は, 2014 年 に全国にある $2 \mathrm{~m}$ を超える約 70 万橋の橋梁について 5 年 に1度の点検が義務化され，点検を支援する新たな点検機 器の開発が期待されているからである. 現在の橋梁点検

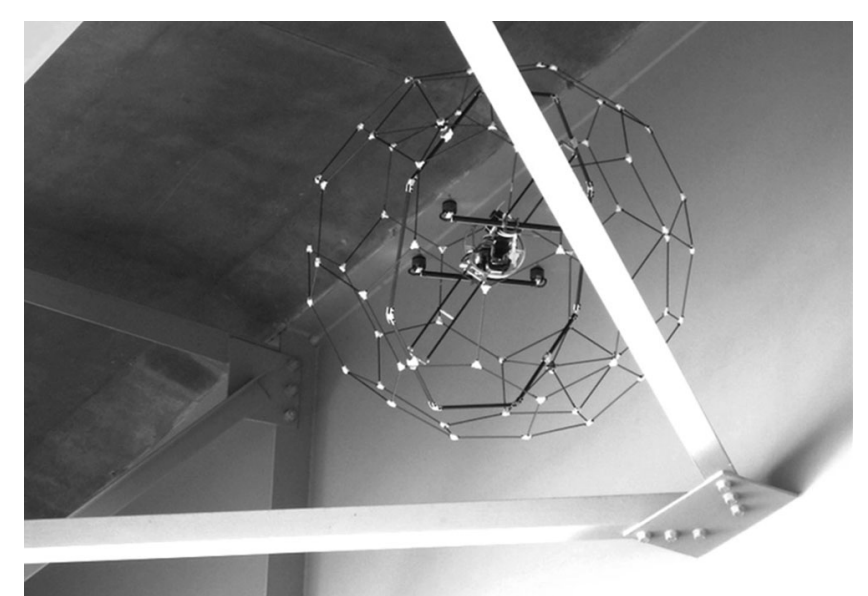

図 1 飛行ロボットを利用した橋梁の近接撮影

*原稿受付 平成 29 年 10 月 2 日

*東北大学未来科学技術共同研究センター（仙台市青葉区荒卷字青葉 468-1 田所研究室)

***東北大学大学院情報科学研究科（仙台市青葉区荒卷字青葉 468-1 田所研究 室)

(株)リコー中央研究所（横浜市都筑区新栄町 16-1）

け(株)千代田コンサルタント（東京都北区西ヶ原 3-57-5)
は, 人による近接目視と, 点検用ハンマーを用いた打音に より行われている。私たちは，この近接目視や打音による 点検を支援する飛行ロボットシステムを開発している.

本稿では, 図 1 に示す橋梁の近接目視点検を支援する飛 行ロボットシステムの開発について説明する. 開発中の橋 梁点検システムは, 橋梁を近接撮影する飛行ロボット, 近 接画像から橋梁の展開画像を自動生成するソフト, 展開画 像を利用して点検調書作成を支援するソフトから構成され る. 開発中の点検システムの特徵は, 球喨へリを用いるこ とで桁間や床版にぶつかっても墜落せずに, 近接画像を撮 影できること, 展開画像を利用して近接画像で見つけた損 傷の位置を特定することである。本稿では, 橋梁を近接撮 影する飛行ロボットの概要と特徵と, 現場適用を中心に, 現在の開発状況を説明する.

\section{2. 飛行ロボットを利用した橋梁点検と特徵}

図 2 に飛行ロボットを利用した橋梁点検の流れを示す. 受動回転球殼へリ（以下, 球殼へリと省略）を利用して, 橋梁の近接画像を撮影する。操縦者は, 河岸などから球殼 ヘリを目視で確認しながら, プロポで操縦する（有視界内 飛行)，並行して，映像に取りこぼしがないことを，操縦 者とは別の人が機体カメラの映像を見ながら確認する。機 体のカメラ映像は電波で伝送され, 手元のタブレット PC の画面で確認することができる.

撮影終了後, 飛行ロボットで撮影した橋梁の近接画像を 回収し，現場から持ち帰ってオフラインで近接画像をつな ぎ合わせて展開画像を生成する。点検員は, 展開画像と近 接画像を利用して, 損傷の位置と種類を特定し調書を作成 する，損傷位置の特定を支援するため，近接画像上で人手 により損傷に印を付けると, 展開画像上の損傷の位置にも 印が自動で付く．また, 展開画像と橋梁の CAD 図面を位 置合わせすることで, CAD 図面上の損傷位置にも自動で 印が付けられる。

私たちが提案する飛行ロボットを利用した点検の特徵 は，(1)従来の橋梁点検で行われていた交通規制に比べて簡 単な規制で点検を実施できること, (2)桁下の高い橋梁につ 


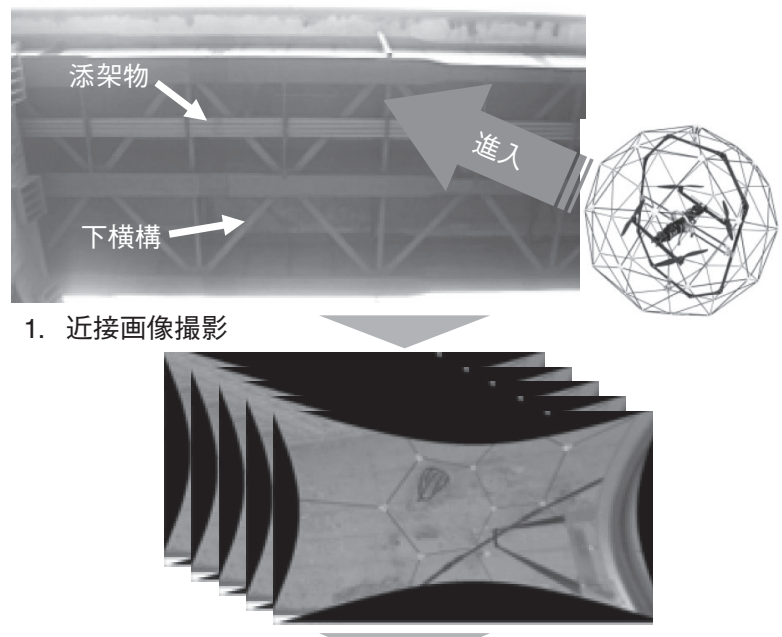

2. 展開画像生成

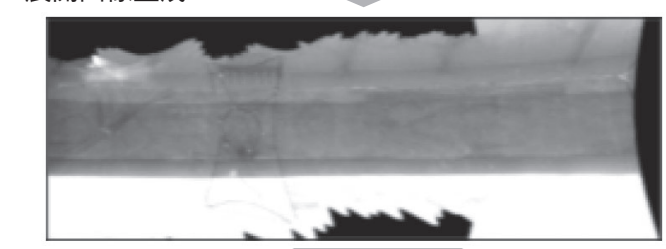

3. 点検調書作成

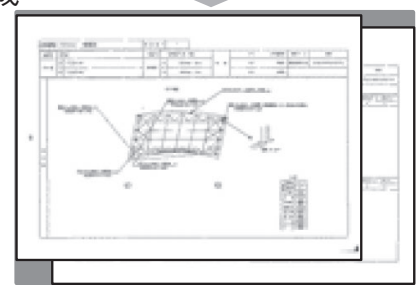

図 2 飛行ロボットを利用した橋梁点検の流れ

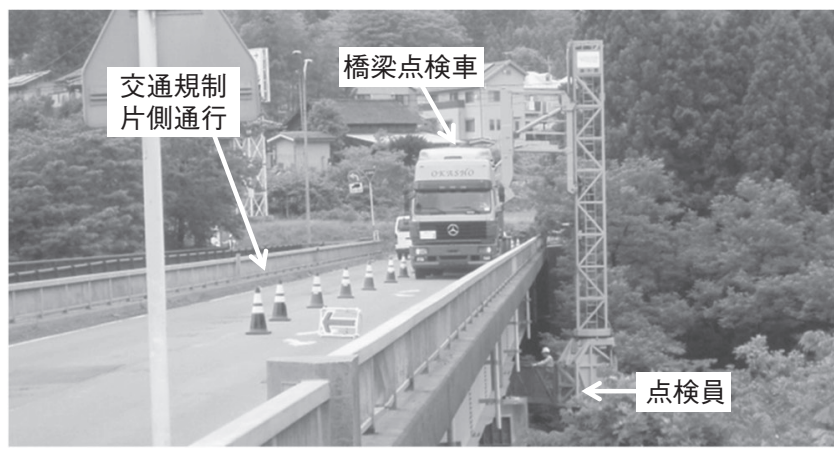

図 3 橋梁点検車を利用した従来の橋梁点検

いても足場などを組まずに点検を実施できること，(3)橋梁 の損傷部と健全部のすべての部位の記録が残ることである.

（1）従来の橋梁点検で行われていた交通規制に比べて簡 単な規制で点検を実施できることについて説明する。図 3 に従来の橋梁点検車両を利用した橋梁点検の様子を示す. 桁下の高い橋梁の点検は，アームを有する点検車を利用し て行う、橋梁点検車を利用する場合, 車線規制等の安全策 を行いながら，橋梁点検車を橋梁の車道等に停車し，アー ムの先のバケットに点検員が乗り込んで，アームを伸ばし て点検箇所に近づいて, 目視や打音による点検を行う。橋
梁の幅や桁高によって，利用する点検車両の大きさが変わ るものの, 一般的には, このような安全規制を行って点検 する，飛行ロボットを用いることで，車両を停車するため の車線規制が不要になり, 交通規制を最小限に抑えて点検 を行うことができると考えている。また，安全確保のため の点検員の数や，交通規制が周囲に与える影響を軽減する ことも期待できる。

（2）桁下の高い橋梁についても足場などを組まずに点検 を実施できることについて説明する，橋梁の下の河岸など から，飛行ロボットを目視で確認しながら飛行させて，点 検に必要な近接画像の撮影を行うことで，足場などを組ま ずに，点検を行うことができるようになる。これまでの実 証実験で, 桁下が $20 \mathrm{~m}$ の橋梁の近接撮影にも成功してい る.

（3）橋梁の損傷部と健全部のすべての部位の記録が残る ことについて説明する。従来は, 点検員が損傷を目視や打 音で確認し, 確認した損傷の種類や位置をカメラで撮影し たり，野帳と呼ばれるノートに書き込んだりして，記録に 残した。 また，事務所に戻ってから，これらの情報に基づ いて点検調書を作成した。 しかし，このような点検方法で は，健全と判断した箇所の情報がほとんど残っていないと いう課題があった。点検の際に, 以前の点検調書では報告 されていなかった損傷が見つかった場合は, 以前の点検デ 一夕と比較しながら新しく見つかった損傷の原因等を検討 することが極めて困難であった，飛行ロボットで全面の記 録を残すことで，記録を基に議論したり，第三者が点検を 検証したりすることができるようになる。

\section{3. 橋梁の近接目視に適した飛行ロボットの開発}

私たちが開発した球殼へリを図 1 に示す。受動回転する 球殼をもつことで, 橋梁にぶつかっても落ちない飛行ロボ ットを開発した ${ }^{122)}$. 図 4 に球款へリの構成要素を示す. 球殼へリは，市販のドローンとガードの役目を果たすフラ ーレン構造の球殼を, 3 軸のジンバル機構でつなげた構造 になっている，床版等を撮影するために桁間に進入する際 に, 周囲の桁, 床版, 添架物にぶつかっても, 球殼がプロ ペラや機体を保護する。また, 衝突した際に球喨が受動的 に回転することで，ヘリに直接外力が加わるのを防ぐ．

球殼の大きさが直径 $0.96 \mathrm{~m}$, 飛行ロボット全体の重さ が $2.6 \mathrm{~kg}$ である. 球殼の直径の大きさは, 全国の橋梁図 面を参考に決めた５12 橋の橋梁図面（コンクリート橋 325 橋，鋼橋 187 橋）を調查し，コンクリート橋，鋼橋と もに枌の間に入ることができる $1.1 \mathrm{~m}$ 未満の大きさの球殼 を作製した，図 5 に, 鋼橋の桁間の調查結果を示す、鋼 橋の場合, $1.3 \mathrm{~m}$ 未満であれば桁の間に進入できることを 示している.

また，撮影用のカメラは，対角で $120^{\circ}$ 以上の広視野角 のカメラを上向きと横向きの 2 台搭載した。対象に $0.5 \mathrm{~m}$ 程度まで近づいて近接撮影を行うことができるため, 小型 軽量で高解像度のカメラを点検に利用する。空撮等で利用 


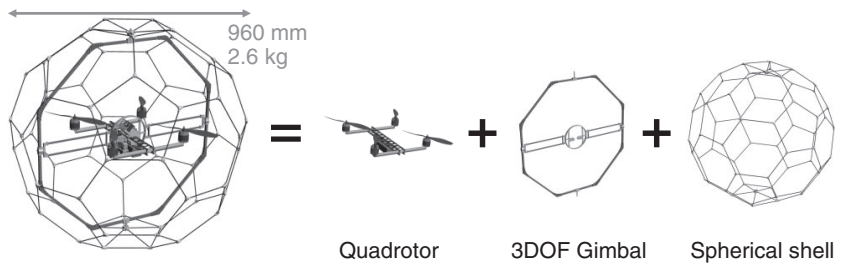

図 4 受動回転球殼ヘリの構成

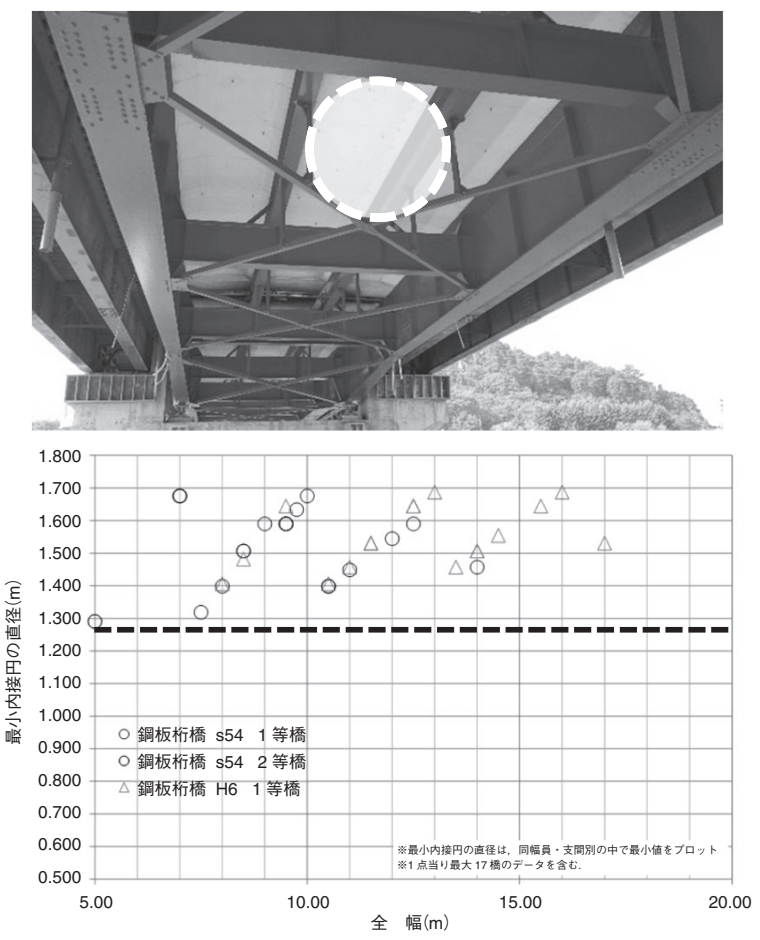

図 5 橋梁の点検に適した球殼のサイズの調査（鋼橋の例）

される機械式のシャッターや大型の CMOS センサを搭載 したハイエンドなカメラを利用せずに, 点検に必要な画像 を撮影する。また，小型カメラにすることで機体重量を $2.6 \mathrm{~kg}$ と軽量にすることが可能になった。

最後に, 球殼の形状も複数検討した。ジオデシックドー ム構造から, フレーム数の少ないフラーレン構造の球殼に 変更することで，球殼の重さを $76 \%$ に軽量化するととも に, 風から受ける抵抗の軽減と, 映像に写るフレームの数 の削減を行った。

このような工夫を行うことで, 最大 $9.9 \mathrm{~m} / \mathrm{s}$ の風の中で 飛行し，橋梁の桁間に進入し近接画像を撮影寸ることがで きる球款へリを開発した。

\section{4. 実橋梁を利用した実証実験}

球殼へリを利用した橋梁点検の実証実験を，各自治体の 橋梁を扮借りして行っている。結果の一部を報告する.

\section{1 高所にある橋梁床版撮影の実証実験}

2016 年 11 月末に, 岐阜 SIP (六郷先生) の提供する岐 阜県岐阜市の千鳥橋（図 7）を抢借りして飛行ロボットを
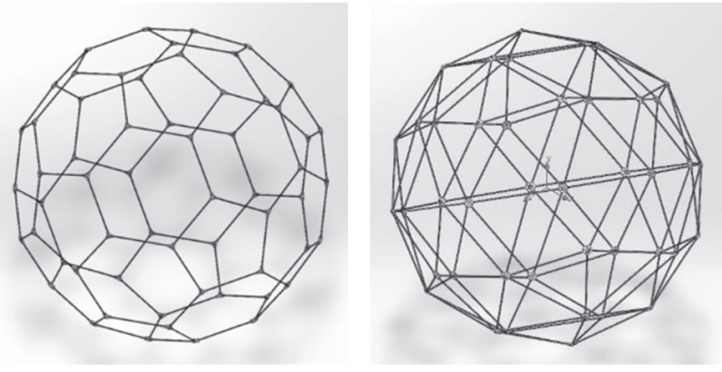

図 6 球殼ヘリの構造の検討：(左) 現在の球殼（フラーレン構造） （右）以前の球殼（ジオデシック構造）

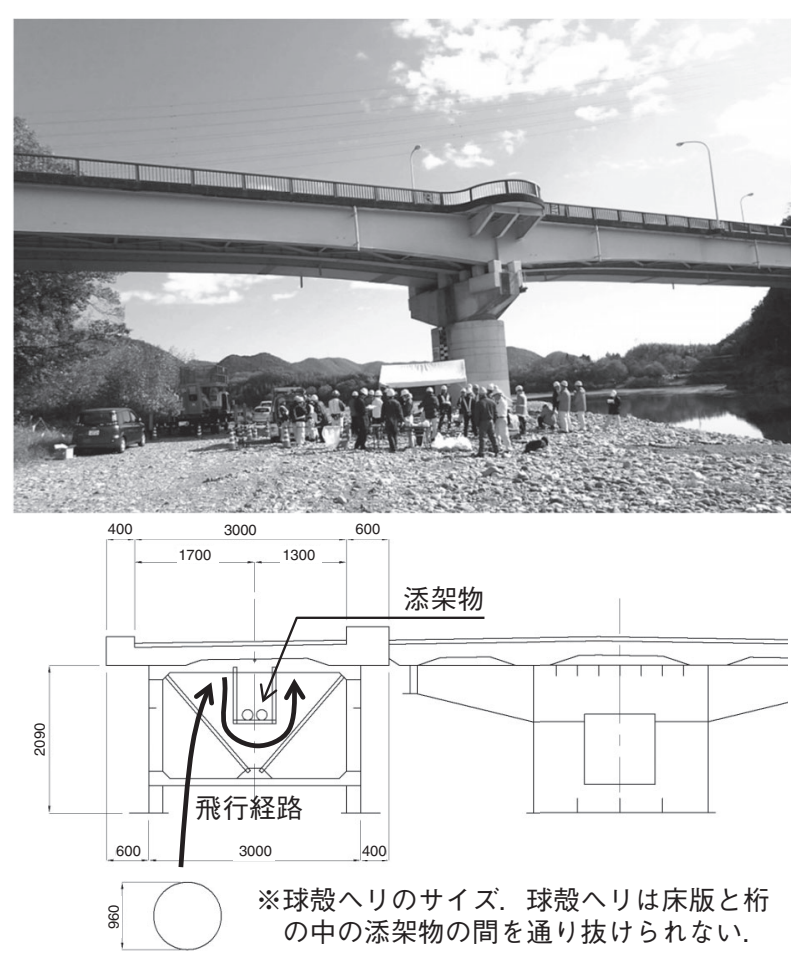

図 7 高所にある橋梁床版撮影の実証実験（岐阜県岐阜市千鳥橋）

利用した橋梁点検の実証実験を行った，桁下の高い橋梁の 歩道側の床版を球凯へリで近接撮影した。歩道の幅は 3.6 $\mathrm{m}$ で，直径 $1 \mathrm{~m}$ の球殼へリで桁間に進入することができ た。一方で，図 7 に示すように桁内には添架物が存在し， 添架物と床版の間を球殼へリで通り抜けることができなか った。

実証実験では，橋梁の CAD 図面を基に飛行ロボットの 飛行経路を策定し，桁内の添架物の左右から床版を撮影す る飛行経路を飛行した (図 7 中の矢印)。広視野角のカメ ラを搭載した球殼へリで, 左右から撮影することで, 床版 全体の撮影を行うことができた ${ }^{3)}$.

図 8 (a) に撮影した近接画像の一例を示す。橋梁のコ ンクリート損傷が撮影できていることが確認できる。図 8 （b）に大量の近接画像をつなぎ合わせて作成した展開画 像を示す. 図 8 (a) の近接画像と図 8（b）の展開画像を 利用して，点検員が作成した調書を図 8 (c) に示す。点 


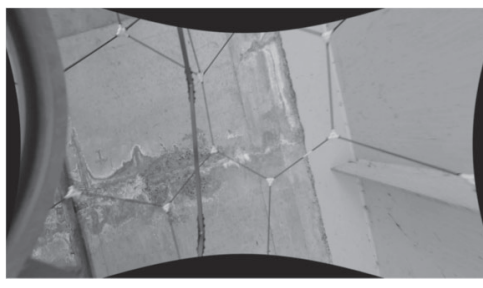

(a) 近接画像

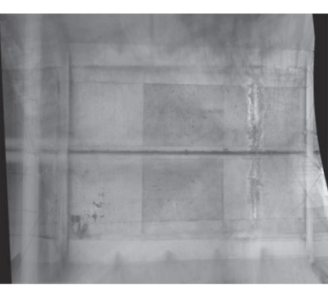

（b）床版の展開画像

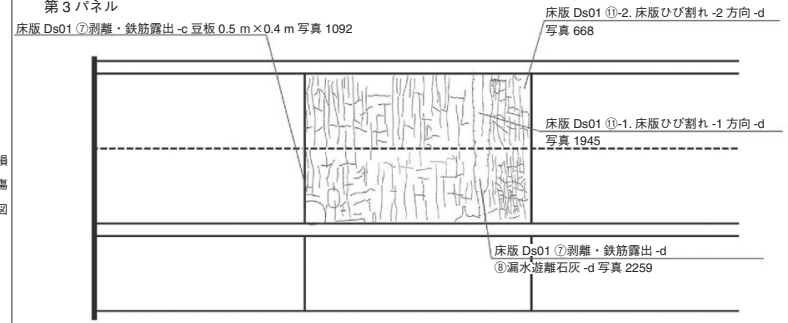

（c）近接画像と展開画像から作成した床版損傷図

図8 近接画像と展開画像を利用した橋梁点検の結果

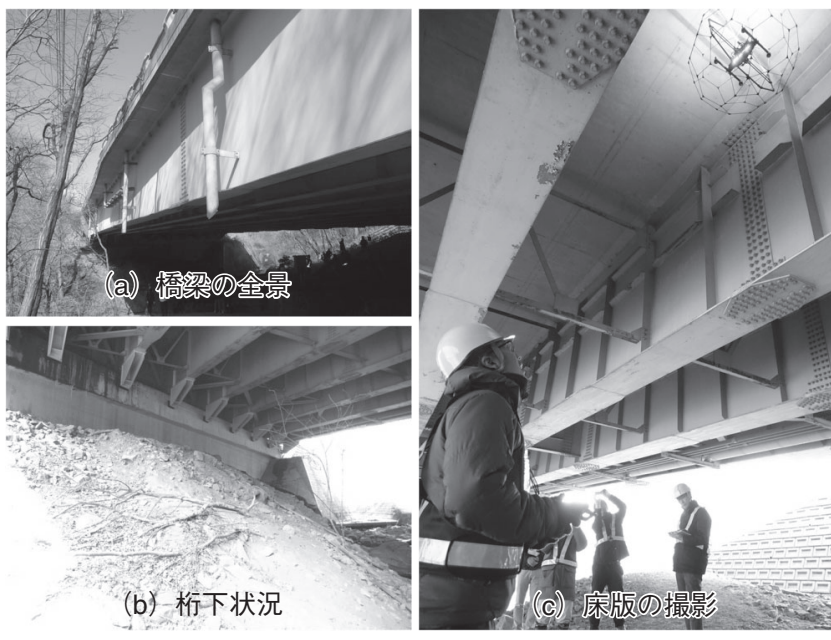

図 9 昼間でも薄暗い橋梁点検の実証実験（宮城県仙台市龍沢橋）

検調書は国交省の指定するフォーマットで作成している が，表示スペースの都合で，損傷が書き込まれた CAD 図 面の部分だけを切り出した結果になる。

この実証実験を通して，球喨へリを利用することで，桁 下の高い橋梁で点検用の足場を組むことなく，また，橋の 上部で大規模な交通規制を行うことなく，橋梁の近接画像 を撮影し，展開画像を生成し，点検を行えることを実証し た。

\section{2 昼間でも薄暗い橋梁点検の実証実験}

2017 年 5 月中旬に宮城県仙台市の龍沢橋を，仙台市の 近未来技術実証特区の枠組みを利用して扔借りし，球殼へ リの実証実験を行った，龍沢橋の特徵は，桁下が低いため 昼間でも薄暗いこと，桁高が $2 \mathrm{~m}$ 以上あり点検車両を利 用しても床版の近接目視が難しいことである(図 9)。薄 暗い床版を撮影するために，LED 照明付きのカメラシス テムを開発し，実証実験を行った。

図 9 (c) に，球殼へリで飛行し，LED 照明で周囲を照
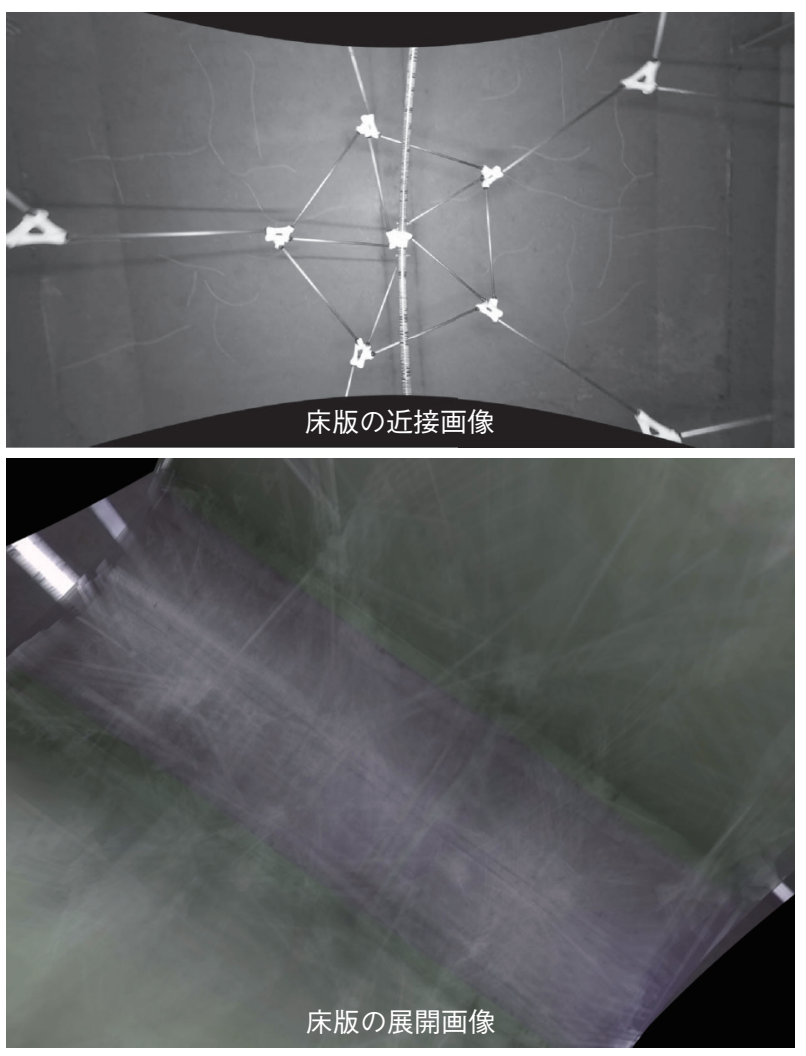

図 10 LED 照明付きカメラで撮影された近接画像（上）と展開画像 (下)

らしながら床版の近接画像を撮影している様子を示す。操 縦者が球殼へリを目視で確認しながらプロポで操縦し, 薄 暗い桁の中の床版を撮影した。

図 10 に，撮影した近接画像と，展開画像を示す。近接 画像の床版には傷と, 以前の点検で付けられたチョーキン グが写っている。本原稿の画像の解像度からは確認が難し いが，元画像に扔いて損傷が写っていることを確認した。 また，暗闇で撮影した近接画像から，損傷の位置特定に利 用する展開画像が生成できることを確認した。

この実証実験を通して，薄暗い橋梁の点検にも球殼へリ が利用できることを確認した。

\section{5. を め め}

本稿では，橋梁の近接目視を支援・代替する飛行ロボッ トシステムについて, 紹介した。飛行システムを利用した 点検の流れ, 特徵について説明した。また, 受動回転球殼 ヘリの概要について紹介した。最後に，飛行ロボットシス テムを利用した橋梁点検の実証実験について 2 例，桁下が 高い橋梁の空撮点検と, 桁下が薄暗い橋梁の空撮点検につ いて, 実証結果を報告した。今後は, 現場適応に向けて, 実証実験から明らかになった球殼の強度などの改善に取り 組む。 また, 同様の点検方法の新たな適応先についても模 索する。 
謝

辞

本研究は, 内閣府総合科学技術・イノベーション会議の 「SIP インフラ維持管理・更新・マネジメント技術」（管 理法人：NEDO）によって実施されました.

\section{参 考 文 献}

1) C.J. Salaan, Y. Okada, K. Hozumi, K. Ohno and S. Tadokoro: Improvement of UAV's Flight Performance by Reducing the Drag Force of Spherical Shell, Proc. the 2016 IEEE/RSJ Intl. Conf. on Intelligent Robots and Systems (IROS2016), (2016) 17081714.

2) 岡田佳都, 岡谷貴之: 橋梁点検を代替するための受動回転球殼 を有するマルチコプターの開発と実橋梁における点検性能評価, 日本ロボット学会誌 34, 2 (2016) 119-122.

3）岡田佳都, 大野和則, 原島正豪, 横江政和：球殼 UAV からの 橋梁接写画像のパノラマ展開による難アクセス床版の損傷マッ ピング，第 17 回建設ロボットシンポジウム, P1-6, (2016).

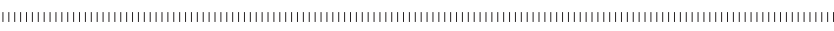

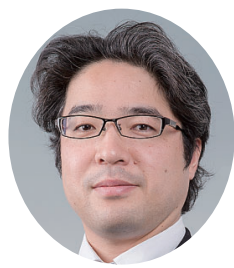

\section{大野和則}

2004 年筑波大学大学院工学研究科知能機能工学 専攻博士課程後期課程修了 (工学). 同年神戸大 学大学院自然科学研究科 COE 研究員, 2004 年 に東北大学工学研究科助手, その後, 助教, 講 師を経て, 2012 年に未来科学技術共同研究セン ターの准教授、現在に至る。レスキューロボッ ト， 3 次元計測，ロボットの自律知能に関する 研究に従事. RSJ データ工学ロボティクス研究 専門委員会委員長. IEEE，日本ロボット学会の 正会員.

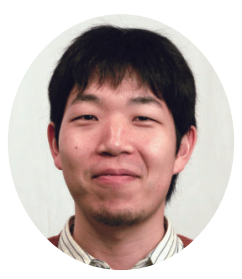

\section{岡田佳都}

2012 年 3 月に東北大学大学院工学研究科航空宇 宙工学専攻博士課程後期 3 年の課程修了. 米力 ーネギーメロン大学での 1 年間の客員研究員を 経て、2013 年 4 月より東北大学大学院情報科学 研究科田所研究室助教。これまで, 福島第一原 発探查に活用されたクローラ型ロボット Quince, 惑星探査ロボット, インフラ点検用飛 行ロボットの開発に従事. 博士 (工学). ロボッ 卜学会正会員

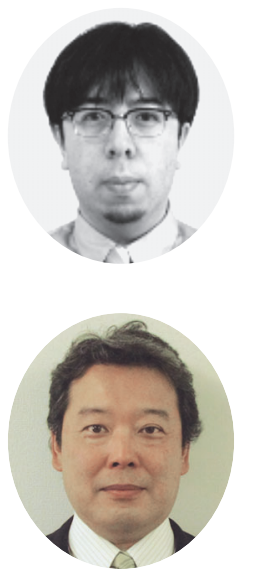

\section{原島正豪}

1994 年東京大学大学院総合文化研究科広域科学 専攻広域システム科学系修士課程修了, 同年 (株)リコー入社. 日本バーチャルリアリティ学 会会員.

\section{横江政和}

1992 年名古屋工業大学工学部社会開発工学科卒 業. 同年 (株) 青木建設入社. 2000 年(株)千代田 コンサルタント入社. 2002 年技術士（建設部 門）取得. (一社) 建設コンサルタンツ協会道路 構造物委員会委員.

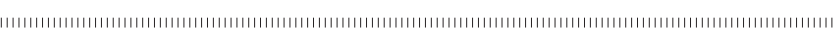

